\title{
Thomas F. Mayer
}

The Roman Inquisition: A Papal Bureaucracy and Its Laws in the Age of Galileo.

Haney Foundation Series. Philadelphia: University of Pennsylvania Press, 2013.

Pp. 385. Hb, \$79.95.

The now two-decade-old renaissance in studies of the early modern inquisitions has reached a point where large-scale syntheses have begun to appear. The works of Christopher Black, Andrea Del Col, and Francisco Bethencourt in particular have provided overviews of inquisitorial operations across early modern Europe and in the colonies. But remarkably, despite these works and the more narrowly focused studies that preceded them, the Sacred Congregation of the Holy Office, or Roman Inquisition, has not been subject to a detailed examination for its own sake. Thomas Mayer's work fills, in large part, this deep hole in the literature and will be indispensable for future work on the Catholic inquisitions.

Mayer reveals in the work's introduction that he did not, in fact, set out to write a book about the Inquisition. As his subtitle hints, his real target was the trial of Galileo, and he only intended a chapter examining the Inquisition. That chapter grew not only into this book but also into a future volume on the Roman Congregation's relationship with local tribunals. (He promises the Galileo book will also eventually emerge.) This work, then, takes a somewhat restricted view, examining the roots and operation of the institution that condemned Galileo and not looking much beyond the era of his trial.

The Congregation of the Holy Office in Rome had a dual role. It provided oversight of and guidance to local tribunals, particularly those in the Italian peninsula, and also served as the tribunal for Rome, trying locals and those defendants sent or brought to the city from elsewhere. Mayer offers a detailed history of the institution largely based on a prosopographical survey of everyone from the popes down to the assistant notaries and, apparently lowest of them all, the archivists. The middle chapters (two through four) contain the details of the inquisitorial offices and the biographies of their occupants, mainly covering their origins, training, offices held before and after serving with the Roman Inquisition, and patronage connections. These chapters are framed by a general overview of the institution (chapter one) and an exploration of the legal theories underlying the process of inquisitio and how that legal underpinning evolved through the seventeenth century (chapter five). The only drawback of this legal analysis is that there is little insight into the extent to which these theories were reflected in practice, given the almost complete loss of the Roman court's trial dossiers. 
Indeed, it is not easy to shed light on virtually any part of the inner workings of the Roman Inquisition. Secrecy was an essential element of inquisitorial activities and, as Mayer ably shows, the personnel of the tribunal often showed a markedly relaxed approach towards documenting the Congregation's activities. And then Napoleon came along. Nonetheless, Mayer has stitched together a wide range of sources to produce a remarkably vivid picture of the inquisitorial bureaucracy. From the Holy Office archives, he relies foremost on the registers of decrees which, though frustratingly limited in some respects, do offer a great deal of information to the careful reader. And Mayer is a very careful reader. He is especially attentive to the currents of status, patronage, and power flowing beneath the surface of seemingly banal elements, such as meeting attendance lists. Mayer supplements his sources from the inquisitorial archive with abundant reading in an array of other libraries and archives, drawing particularly on diplomatic correspondence and the early modern newsletters that passed on the latest colorful curial gossip.

Mayer's most valuable contribution is to show in detail who did what, how, when, and why in the Roman Inquisition. His attention to detail is marvelous; the text and especially the notes are filled with corrections of the existing secondary literature. But he also offers some key analytical points. He argues that the Congregation of the Holy Office was, more than other curial bodies, a creature of the pope-a fact that became increasingly important over time. He shows that standards for the cardinal inquisitors and the inquisitorial staff gradually declined as popes, particularly those who had not themselves been cardinal-inquisitors and above all Urban VIII, came to see personal loyalty as the most important qualification, displacing theological or legal training and inquisitorial experience. Although Mayer notes the rules governing the operation of inquisitions, he swims against the historiographical current in circumscribing the impact of those rules. He argues convincingly that they constrained local tribunals much more than they did the pope and cardinals in Rome, as he shows that the Roman tribunal was built for flexibility and when that flexibility was insufficient for their needs, popes could and did simply force the issue. On this score, he again singles out the later, non-inquisitorial popes and especially Urban.

Mayer packs an enormous amount of information into a compact text. The body of the book barely tops 200 pages, though the appendices and notes add another 150 . There are some drawbacks to this concision. Readers will have an easier time if they have at least a passing familiarity with the curial world of referendaries, breves, commendatory chapels, and so forth, as definitions sometimes come well after the introduction of terms, if at all. Some readers might find the chronological and topical limitations of the book (consequences 
of the Galilean roots of the project) frustrating. But that is mainly a sign of the value of this work: one wishes Mayer had told more of the story. As it stands, this work will be fundamental for anyone seeking to understand the early modern inquisitions.

\section{Jonathan Seitz}

Department of History and Politics

Drexel University

jwseitz@drexel.edu 